Int. J. Dev. Biol. 50: 371-375 (2006)

doi: $10.1387 / \mathrm{ijdb} .052125 \mathrm{kc}$

Special Contribution

\title{
Morphological innovation through gene regulation: an example from Devonian Onychodontiform fish
}

\author{
KENTON S.W. CAMPBELL* and RICHARD E. BARWICK \\ Department of Earth and Marine Sciences, Australian National University, Canberra, Australia
}

\begin{abstract}
The recent development of novel phenotypic designs by changes in gene regulation has been extensively discussed within the context of evolution and development. The fossil record shows many new designs (or body plans) which appear rapidly at various stratigraphic levels. One example of this is the arrival of the lobe finned fish in the Early Devonian, when a great variety of new forms appeared. These include the dipnoans, the onychodontids, the porolepiforms and the osteolepiforms, which differ widely in a number of characters. Each of these groups originated from an unspecified sarcopterygian source and they have since evolved independently. They also carry over the primitive genes of the parent or parents and similar changes in these genes will not produce synapomorphies between members of the different lineages. Unless care is exercised, homoplasies will be used as synapomorphies. Evidence must be found to find groups of features that define uniform functional entities. These define monophyletic groups. Recognition of homoplasy of characters thus becomes important. The study of the new functional structures and the areas from which they were derived by changes in gene regulation, would give us more evolutionary information.
\end{abstract}

KEY WORDS: gene regulation, sarcopterygians, evolution, functional analysis, homoplasy

\section{Introduction}

Recent work on the genetic basis for the development of new morphologies, has highlighted the role of changes in gene regulation in producing new evolutionary lineages. Sarcopterygian fish that showed radiation near the beginning of the Devonian, provide an excellent example of such diversification. Each new lineage will contain new genetic structures, but as the same sarcopterygian group formed the ancestral group, some primitive ancestral genes will be carried into each new lineage. These primitive genes may alter independently in the separate lineages either by point mutation or by further changes in gene regulation and in so doing they will produce similar features (Fig. 1).

Recent attempts to understand relationships between different sarcopterygian groups have been based on cladistic methods and these depend on comparisons between many characters in the different lineages. Many of these will be based on features that have arisen independently in the lineages and hence cannot be synapomorphies. Instead they will be the result of homoplasy and distinguishing such structures will be difficult if not impossible. And cladists tend to use all characters and then use the most parsimonious tree. We do not accept this approach because an analysis of parsimony logically cannot apply to the study of individuals which are themselves not stable in character. The method can be used for physically constant characters, but if the entities used are biological characters which themselves are subject to change, the method does not apply.

It is our view that each lineage, or each monophyletic group, should be defined on the group of characters that were incorporated in the lineage at the tine of changes in gene regulation. These will be recognised by the fact that they will be related functionally and constructionally. In an attempt to understand the difficulties we now face, we examine the cladistic relationships of one group of sarcopterygians with which we have examined in detail - the Onychodontiformes.

\section{Rapid changes in the origin of the Onychodontiformes}

We have concluded that in the Early Devonian the Dipnoi, the Onychodontiformes, Osteolepiformes, Porolepiformes and Actinistia, all members of the Sarcopterygii, underwent changes by which new designs were produced. Most workers agree that the period close to the Siluro-Devonian boundary was where new structures within the sarcopterygians were introduced. This matter is discussed below.

A summary of the effects in the fossil record of rapid changes

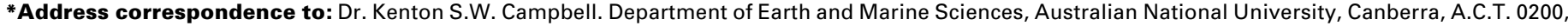
Australia. Fax: +61-2-6125-5544. e-mail: ken.campbell@anu.edu.au
} 

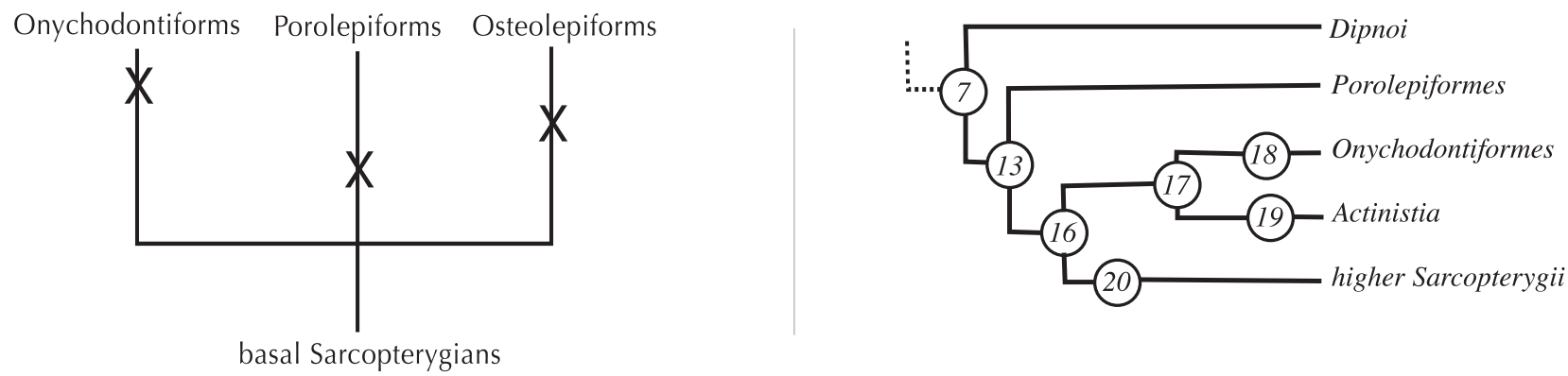

Fig. 1 (Left). Changes in gene regulation from their origin in basal Sarcopterygii. Some new evolutionary lines are indicated and the crosses indicate where new features are developed independently in each line from the parent genes which may produce homoplasies.

Fig. 2 (Right). A modified version of part of the cladogram produced by Zhu \& Schultze (2001), not using generic names but the names of major groups. The node numbers are the same as those in the original diagram and Node 16 is as mentioned in our text.

in several groups can be found in Valentine and Jablonski (2003) and they suggest "that the richness of higher taxa is not driven by cladogenesis among species, but rather is acquired by selective processes within lineages that may even be species poor." The same point is made by analysis of structure rather than taxonomic work. This is significant material because the study of fossil material gives an increasing impetus to the evolution and development revolution.

The causes of these gene regulatory changes were illustrated by the following quotations from molecular geneticists. Carroll (2000) in his work on the extent of gene regulation, includes the statement that the "....regulatory DNA is the predominant source of genetic diversity that underlies morphological variation and evolution.... Individual elements can act and therefore evolve independently of others." Davidson (2001) in his summary of the changes that make new forms, concludes that " ... there is no other way to conceive of the basis of evolutionary change in bilaterian form than by change in the underlying developmental gene regulatory networks". Later the author comments that "...consider the bursts of evolutionary change in morphology, followed by periods of stability, which is suggested by some aspects of the bilaterian fossil record." And finally he indicates that "The result of

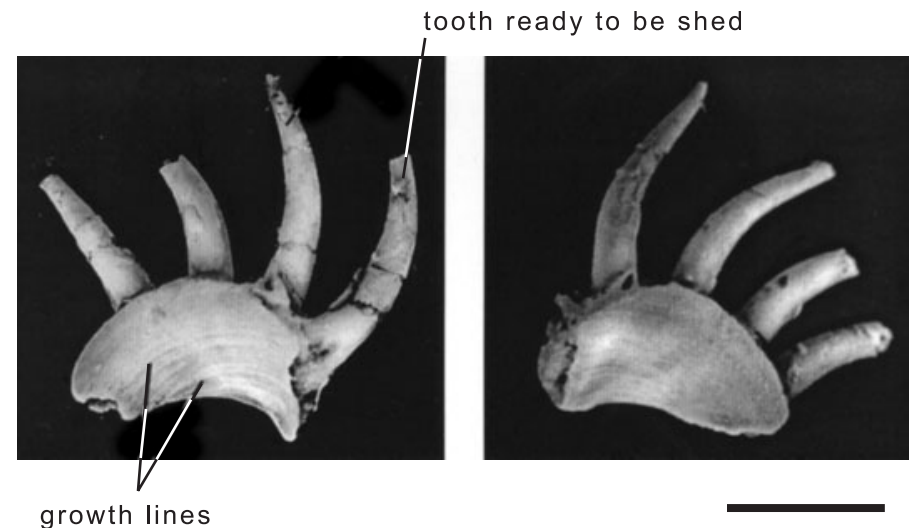

a successful upstream change of this kind is to create a new set of possibilities downstream, a 'morphospace' to fill....Given that gene networks have upstream and downstream polarities, major evolutionary change in developmental processes must be at a discontinuous rate".

\section{The Onychodontiformes}

The most recent attempt at a cladistic analysis was by Zhu and Schultze (2001). In regard to the Sarcopterygii, Cloutier and Ahlberg (1995) asked the question:- how far are we from a phylogenetic consensus? Since that date new articles have continued to appear relating new discoveries in Yunnan, China and to new information on already described genera (Yu Xiaobo, 1998; Zhu, Yu and Janvier, 1999; Zhu, Yu and Ahlberg, 2001; Zhu and Schultze, 1997; Long, 2001; Chang, 2004). Another recent work (Zhu and Yu, 2004) comments on the mandibles of Early Devonian genera from Yunnan and deals with the possible origin of onychodontiform genera.

In addition to the Onychodontiformes a whole new range of new body plans appeared at that time. We note Psarolepis,

Fig. 3 (Left). Two symphysial tooth whorls from the Gogo species of Onychodus. The left specimen shows the growth lines on the whorl surface and a tooth on the right side ready to be lost. See also Fig. 4. The right specimen viewed internally with some of the small denticles visible anteriorly.

Fig. 4 (Right). Illustration of the symphysial tooth whorls with the new teeth in the posterior part of the whorls before they were inserted and a tooth being lost at the anterior end. 


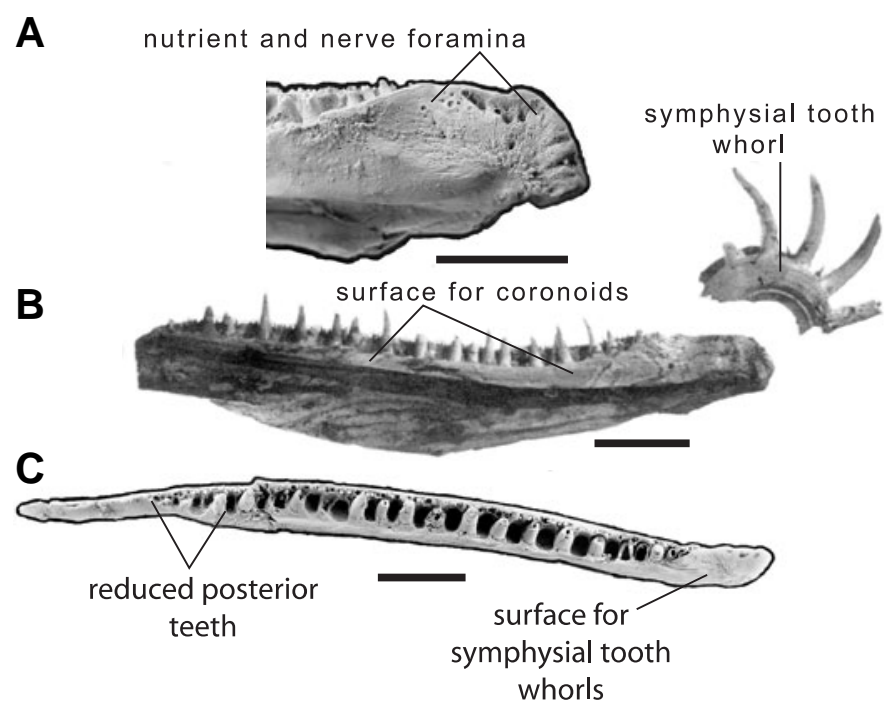

Fig. 5. Onychodus mandibular morphology. (A) View of the anterior part of another specimen showing the foramina for the nerves and blood vessels supplying the soft tissues on the margins of the symphysial tooth whorls. (B) Internal view of a mandible, broken posteriorly but showing the swelling of the dermal plates where the symphysial teeth were attached. Compare with the specimens illustrated by Zhu and Janvier (1994). (C) Dorsal view of the mandible showing the disribution of the teeth along the dentary. Arrangement of teeth at each end unique for Onychodontiformes. Teeth bent upwards and inwards

Achoania, Styloichthys, Langdenia, Youngolepis and an unnamed mandible, all of which are regarded as stem sarcopterygians, as well as Diabolepis which is commonly regarded as a dipnomorph.

We are concerned in this paper with the Onychodontiformes and to illustrate the problem, we refer to part of the cladogram (Fig. 2) prepared by Zhu and Schultze (2001). This is based on a data matrix which, in Node 16, holds together the onychodontiforms / actinistians on the one hand and the higher sarcopterygians on the other. As is noted by Zhu and Schultze, Node 16 includes one reversal, four ambiguous characters, one character (121) which it also shares with the Dipnoi and two unencumbered characters. (Character 121 refers to the denticulated spiracular grooves on the parasphenoid, a contestable point). The two unencumbered characters are the median extrascapular overlap and the presence of a foramen in the entepicondylar; that is they refer to a posterior feature of the skull roof and a feature of the pectoral fin. These characters are not connected in any way either by function or by structure. They could be accidental occurrences brought together by the choice of characters to be analysed, or by the programs used to assemble the characters. One can only regard the characters listed above as very tenuous and to base a phylogeny on such features as doubtful. We have not worked over the other nodes in the phylogenetic diagram, but simple observation shows that many of them are similarly tenuous.

\section{Summary of previous Onychodontiform material}

Naturally we would prefer to deal with the earliest Devonian members of the group, but as was shown by many years of work, the fossil skeletons are all dissociated and difficult to reconstruct The material on which we have based our interpretation of the onychodontiforms is from the Gogo Formation of Late Devonian (Frasnian) age in Western Australia. This is the most complete species of the Onychodontiformes yet known and the bones are still in association so that a full description can be made. But it is necessary to examine the earliest known occurrences. Other work on the Struniformes, commonly allied with the Onychodontiformes, is the work of Jessen, (1966) on both the European and American groups. Further work has to be done on the type species of Onychodus, $O$. sigmoides Newberry, (Newberry, 1857) from the basal Middle Devonian to check the mandibular pattern, but the symphysial tooth whorls from the Middle Devonian are of the same kind as those from Gogo.

The new work (Zhu and Yu 2004) on the lower jaws from Yunnan, raises the question of whether the genera Achanoia, Psarolepis and Styloichthys are forerunners of the later Onychodontiformes. It is difficult to make conclusions from limited material, but we note that the anterior of the skull is known from Achanoiaand Psarolepis. In both of these genera there is a space into which the symphysial tooth whorls could pass on jaw closure (Long, 2001) and there is similarity with Onychodus. On the other hand the mandibles of Achanoia and Psarolepis have small spaces wherein the symphysial whorls would fit, five coronoids instead of three, a clear excavated glenoid fossa and a dentary and subdentary pattern which is quite different from that of the Gogo species. In addition they have surface features which need to be investigated. Rather than ally these genera with Onychodontiformes and try to compare transitions between them, we note that these genera arose in the Early Devonian at the time when changes in gene regulation were taking place and it may be that they also were individually involved in making new lineages separately by changes in gene regulation. Maybe we are asking the wrong question. In any case we see that no compelling reason has been made for considering them to be the early members of the Onychodontiformes.

A reference to an older member of the Onychodontiformes is the basal Devonian (Lochkovian) dentary from Yunnan (Zhu and Janvier, 1994). The presence of symphysial whorls is inferred from the swelling of the symphysial region of the mandible. Other members of the group have been reported in the Fairy Formation (Pragian) from the Buchan region in Victoria (Long 1991), but

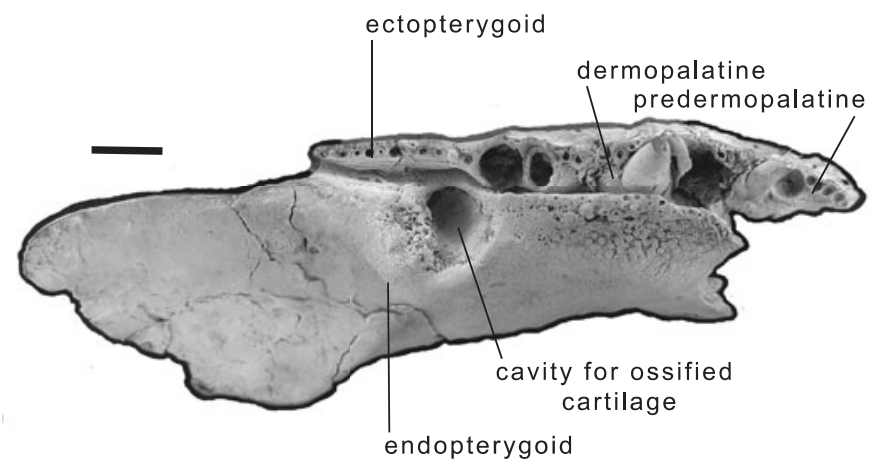

Fig. 6. A left endopterygoid and with the ectopterygoid, dermopalatine and predermopalatine in position. A space indicated for the partly ossified cartilage which guided the mandible during closure. 


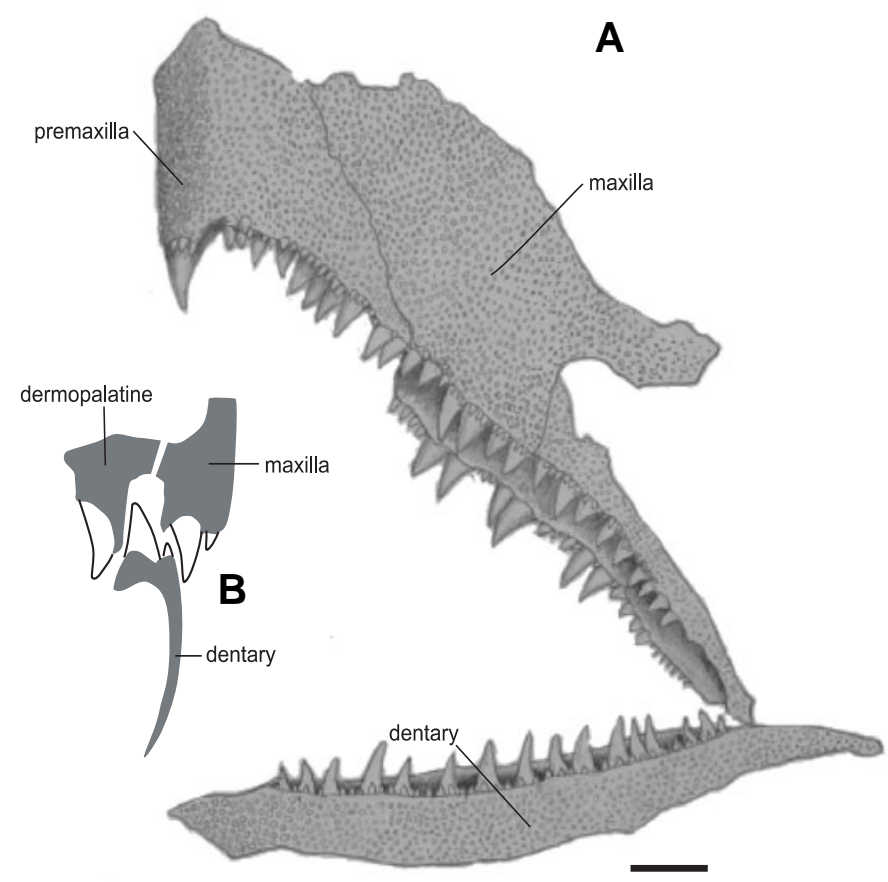

Fig. 7. The Onychodontid bite. (A) Illustration of part of the upper jaw with the maxillary and the ectopterygoid, dermopalatine and predermopalatine in position and (B) how the teeth on the mandible fit between the teeth on these bones during the closure of the mandible.

Long (pers comm.) indicates that many of the features outlined for Gogo, the symphysial teeth, the gap in the pterygoid and the median bone separating the parietals, are also present. Fragments of teeth have been described from the Early Devonian, but these contribute little to the distribution of the Onychodontiformes. Young and Schultze (2005) have described the mandible of a new onychodontid, Luckeus, from the Emsian-Eifelian of Central Australia and this has most of the features found in the Gogo species. The group (Turner et al., 2000) has been recorded from the late Early Devonian through the Eifelian in north Queensland and some of these have teeth indicating the characteristic onychodontiform dentition. The upshot is that skeletal material of the Onychodontiformes can be traced back to the Pragian (mid Early Devonian) and from this level there are characters indicating comparability with the Gogo species. The Lochkovian material is too poor to be sure of its relationships. Assuming that the group took part in the development of several new designs in the Sarcopterygii near the beginning of the Devonian, we now list the apomorphies which define the group from the Late Devonian (Frasnian) material at Gogo. In doing so we recognise that since the Pragian some features must have changed and we will be possibly have some features that have evolved during that time.

\section{New material from Western Australia}

The Gogo material is described in the Transactions of the Royal Society of Edinburgh, (Andrews et al., 2006) and will be published in 2006. As a basis for examination, we have set out the features which are related to the Onychodontiformes and distinguish them from all other Sarcopterygii.

(A) The structure and replacement of the symphysial teeth - (1) the double symphysial mobile tooth rows in the mandible (Fig. 3); (2) the introduction of new teeth in these rows posteriorly and the loss of the anterior teeth during growth (Fig. 4).

(B) Internal structure of the mandible: (3) showing the downturned flange for the coronoids, the space for the attachment of the symphysial tooth whorls and the tapering of the tooth row at each end (Fig. 5).

(C) The structure of the teeth in relation to jaw movements - (4) the presence of a partly ossified cartilaginous mass on the pterygoid to keep the jaws in alignment during the closure of the mandible (Fig. 6); (5) the spacing of the dermopalatine series so that the teeth on the dentary fall between them and the mandibular teeth, making a bite which will not permit lateral movement (Fig. 7).

(D) The structure of the mandibular articulation - (6) the failure of the quadrate to be integrated with the pterygoid and the articular which is not integrated with the mandibular bones, making a flexible mandibular articulation (Fig. 6); (7) the absence of a ball and socket joint in the articulation.

(E) The accommodation of the space for the symphysial teeth during closure - (8) the internasal cavities in the snout into which the symphysial tooth whorls on the mandible would fit (Fig. 8); (9) the loss of the vomers, to permit the symphysial tooth whorls to enter the palate (Fig. 8).

(F) The accommodation of the pectoral girdle to the flexibility of the bite - (10) modification of the pectoral girdle with a flexible arrangement between the cleithrum and the clavicle. The clavicle and the cleithrum are only loosely joined and they are capable of major expansion during swallowing.

This does not include all the features that uniquely identify the Gogo Onychodontiformes, but it does outline most of the charac-

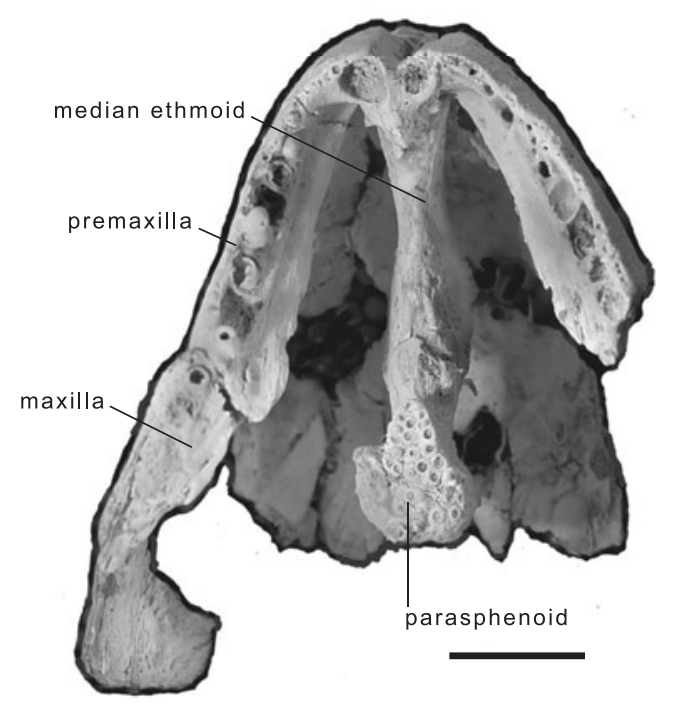

Fig. 8. Ventral view of Onychodus showing the spaces for the symphysial tooth whorls, the median ethmoidal region, the denticulated parasphenoid, the absence of the vomers and the teeth on the premaxilla. 
ters. What is more it shows how the structures are related to the main feeding, grasping and mastication and the movement of the pectoral fins. From the evidence given above we suggest that these features all appeared near the base of the Devonian, but further research is necessary to find other material in Yunnan and in neighboring regions. In this new list of characters there is no evidence of synapomorphies that permit us to ally the group with any other Sarcopterygii, nor is there any evidence of these characters being found in any later Sarcopterygii.

We hypothesise that the Onychodontiformes evolved by changes in gene regulation near the beginning of the Devonian, along with a wide range of new body plans of Sarcopterygii. Rather than attempting to discover relationships between the various groups using cladistic methods which we consider to be misleading, we consider that studying the functional structures that newly appeared at that time and then try to give an integrated study in functional terms, would give a better understanding of the course of evolution.

\section{Conclusion}

Recent work on Devonian Onychodontiformes has produced high quality data and new diverse information about the distinctive features of the group. The new material is from the Gogo Formation of Frasnian age in Western Australia. Literature search has suggested that some poorly preserved members of the group can be found in the Early Devonian and perhaps back to the Lochkovian.

Onychodontiforms can be identified by a large number of characters that are not found together in any other sarcopterygian group. We conclude that the primitive sarcopterygians split into several evolutionary lineages by a process of changes in gene regulation. Each lineage will contain some primitive genes which may become changed independently to produce similar structures. This will produce homoplasy within the sarcopterygians, but these changes may be recognised as synapomorphies. It is of great importance to recognise the independent gene regulated evolutionary lineages before beginning an analysis of character distribution. The origin of new body plans by changes by gene regulation provides the basis on which new evolution can take place.

\section{References}

ANDREWS, S.M., LONG, J.A., AHLBERG, P.E., BARWICK, R.E. and CAMPBELL, K.S.W. Trans, Roy. Soc Edinburgh, (Earth Sciences) (in press)

CARROLL, S.B. (2000). Endless forms: the evolution of gene regulation and morphological diversity. Cel/101: 577-580.
CHANG MEE-MANN. (2004). Synapomorphies and scenarios - more characters of Youngolepis betraying its affinity to the Dipnoi. 665-686. In Recent Advances in the Origin and Early Radiation of Vertebrates. (Eds. Arratia, G., Wilson M.V.H. and Cloutier, R.) Pfeil, München.

CLOUTIER, R. and AHLBERG, P.E. (1995). Sarcopterygian relationships; how far are we from a phylogenetic consensus? Geobios (Memoir Special) 19:241-248.

DAVIDSON, E.H. (2001). Genomic Regulatory Systems: Development and Evolution. Academic Press, New York.

JESSEN, H. (1966). Die Crossopterygier des oberen Plattenkalkes (Devon) der Bergish-Gladbach-Paffrather Mulde (Rheinisches Schiefergebirge) under Bercksichtigung von Americkanischem und Europäischem Onychodus-material. Arkiv. Zool.18: 305-389.

LONG, J.A. (1991). The long history of Australian fossil fishes. In Vertebrate Paleontology of Australasia. (Eds. Vickers-Rich, P., Monahan, J.M., Baird, R.F. and Rich, T.H). Pioneer Design Studio, Monash University, Melbourne, pp. 338428.

LONG, J.A. (2001). On the relationships of Psarolepis and the Onychodontiform fishes. J. Vert. Paleontol. 21: 815-820.

NEWBERRY, J.S. (1857). New fossil fishes from the Devonian rocks of Ohio. Bull. Nat. Inst. Washington New series 1.

TURNER, S., BASDEN, A. and BURROW, C.J. (2000). Devonian vertebrates of Queensland. Courier Forschungsinstitut Senckenberg 223: 487-521.

VALENTINE, J.W. and JABLONSKI, D., (2003). Morphological and developmental macroevolution: a paleontological perspective. Int. J. Dev. Biol. 47: 517-522.

YOUNG, G.C. and SCHULTZE, H-P. (2005). New osteichthyans (bony fishes) from the Devonian of Central Australia. Mitt. Mus. Nat.kd. Berl. Geowiss. Reihe8: 1335.

YU XIAOBO, (1998). A new porolepiform fish, Psarolepis romeri, gen. et sp. nov. (Sarcopterygii, Osteichthyes) from the lower Devonian of Yunnan, China. J. Vert. Paleontol. 18: 261-274.

ZHU MIN and JANVIER, P. (1994). Un Onychodontida (Vertebrata, Sarcopterygii) du Dévonien Inférieur de Chine. Compte Rendues Académie Sciences., Paris. 319: 951-956.

ZHU MIN and SCHULTZE, H-P. (1997). The oldest sarcopterygian fish. Lethaia30: 293-304.

ZHU MIN and SCHULTZE, H-P.( 2001). Interrelationships of basal osteicthhyans. In Major Events in Early Vertebrate Evolution. Palaeontology, phylogeny. genetics and development. (Ed. Ahlberg P.E.). Systematics Association Special Volume Series 61, pp. 289-314.

ZHU MIN and YU XIAOBO (2004). Lower jaw character transitions among major sarcopterygian groups - a survey based on new materials from Yunnan, China. In Recent Advances in the Origin and Early Radiation of Vertebrates. (Eds. Arratia, G., Wilson, M.V.H. and Cloutier, R.). Pfeil, München, pp. 271-286.

ZHU MIN, YU XIAOBO and AHLBERG, P.E. (2001). A primitive sarcopterygian fish with an eyestalk. Nature 410: 81-84.

ZHU MIN, YU XIAOBO and JANVIER, P. (1999). A primitive fossil fish sheds light on the origin of bony fishes. Nature 397: 607-610.

Received: November 2005

Reviewed by Referees: January 2006

Modified by Authors and Accepted for Publication: January 2006 